Editorial

\title{
Special Issue on Plasma Medicine
}

\author{
Mounir Laroussi ${ }^{1, *}$, Michael Keidar ${ }^{2}$ and Masaru Hori ${ }^{3}$ \\ 1 Electrical \& Computer Engineering Department, Old Dominion University, Norfolk, VA 23529, USA \\ 2 School of Engineering and Applied Science, George Washington University, Washington, DC 20052, USA; \\ keidar@gwu.edu \\ 3 Institute of Innovation for Future Society, Nagoya University, Nagoya 464-8603, Japan; \\ hori@nuee.nagoya-u.ac.jp \\ * Correspondence: mlarouss@odu.edu; Tel.: +757-683-6369
}

Received: 2 October 2018; Accepted: 15 October 2018; Published: 17 October 2018

Research on the applications of atmospheric pressure low temperature plasma (LTP) in biology and medicine started in the mid-1990s with experiments on the inactivation of bacteria on biotic and abiotic surfaces and in liquid media [1,2]. This was soon followed by investigations on the effects of LTP on mammalian cells [3-9]. The encouraging results obtained in these early works led to the consideration of LTP technology for new potential therapies in wound healing, dentistry, and cancer treatment [5-9]. By the end of the first decade of the 2000s, many LTP sources had been approved for medical use. These included the Rhytec Portrait ${ }^{\circledR}$ for use in dermatology (approved in 2008), the Bovie J-Plasma ${ }^{\circledR}$ (Clearwater, FL, USA), the Canady Helios Cold Plasma and Hybrid Plasma ${ }^{\text {TM }}$ (Takoma Park, MD, USA) Scalpel, the Adtec MicroPLaSter ${ }^{\circledR}$ (Hounslow, UK, approved for clinical trials in 2008), the kINPen ${ }^{\circledR}$ (developed by INP, Greifswald, Germany, and medically certified as class IIa in 2013), and the PlasmaDerm ${ }^{\circledR}$ device (CINOGY GmbH, Duderstadt, Germany). In addition to potential applications in medicine here on Earth, LTP may prove to be a crucial technology for space medicine. In long-duration manned deep space missions, using LTP for decontamination and wound treatment, for example, would be a more suitable/applicable option than transporting and storing perishable chemical-based medication. In this context. LTP offers energy-based medical options that mostly require the availability of electrical power.

The effects of LTP on biological cells are believed to be mainly mediated by its reactive oxygen species (ROS) and reactive nitrogen species (RNS) [10,11]. These include hydroxyl, $\mathrm{OH}$, atomic oxygen, $\mathrm{O}$, singlet delta oxygen, $\mathrm{O}_{2}\left({ }^{1} \Delta\right)$, superoxide, $\mathrm{O}_{2}{ }^{-}$, hydrogen peroxide, $\mathrm{H}_{2} \mathrm{O}_{2}$, and nitric oxide, NO. These species (radicals and non-radicals) can interact with cells membranes, enter the cells, and increase the intracellular ROS concentrations, which may lead to DNA damage and may compromise the integrity of other organelles and macromolecules [12-16]. ROS and RNS can also trigger cell signaling cascades, which can ultimately lead to cellular death pathways, such as apoptosis. Other plasma-generated agents that may play biological roles are charged particles and photons. In addition, LTP can exhibit large electric fields that are suspected to also play a role, such as in cellular electroporation, allowing large molecules to enter the cells.

This Special Issue contains eight papers discussing the latest results on the application of LTP to various cell lines and tissues. These papers discuss a variety of plasma medicine topics, including the treatment of ovarian cancer, triple-negative breast cancer, malignant solid tumors, new LTP devices, as well as a mini review and a paper describing atomic scale simulations on glucose uptake under LTP treatment.

To conclude, the guest editors would like to thank all the authors for their valuable contributions and the reviewers for their time and efforts. 


\section{References}

1. Laroussi, M. Sterilization of Contaminated Matter with an Atmospheric Pressure Plasma. IEEE Trans. Plasma Sci. 1996, 24, 1188. [CrossRef]

2. Laroussi, M. Sterilization of Liquids Using Plasma Glow Discharge. U.S. Patent 5,876,663, 2 March 1999.

3. Shekhter, A.B.; Kabisov, R.K.; Pekshev, A.V.; Kozlov, N.; Perov, Y.L. Experimental and Clinical Validation of Plasmadynamic Therapy of Wounds with Nitric Oxide. Bull. Exp. Biol. Med. 1998, 126, 829. [CrossRef]

4. Stoffels, E.; Flikweert, A.J.; Stoffels, W.W.; Kroesen, G.M.W. Plasma Needle: A non-destructive Atmospheric Plasma Source for Fine Surface Treatment of Biomaterials. Plasma Sources. Sci. Technol. 2002, 11, 383. [CrossRef]

5. Laroussi, M.; Kong, M.; Morfill, G.; Stolz, W. Plasma Medicine: Applications of Low Temperature Gas Plasma in Medicine and Biology; Cambridge Univ. Press: Cambridge, UK, 2012; ISBN 978-1-107-00643-0.

6. Keidar, M.; Beilis, I.I. Plasma Engineering: Application in Aerospace, Nanotechnology and Bio-Nanotechnology; Elsevier: Oxford, UK, 2013; ISBN 978-0-123-85977-8.

7. Fridman, A.; Friedman, G. Plasma Medicine; Wiley: New York, NY, USA, 2013; ISBN 978-0-470-68970-7.

8. Metelmann, H.-R.; Von Woedtke, T.; Weltmann, K.-D. Comprehensive Clinical Plasma Medicine; Springer: Berlin, Germany, 2018; ISBN 978-3-319-67627-2.

9. Toyokuni, S.; Ikehara, Y.; Kikkawa, F.; Hori, M. Plasma Medical Science; Academic Press: Cambridge, MA, USA, 2018; ISBN 978-0-128-15004-7.

10. Graves, D. The emerging role of reactive oxygen and nitrogen species in redox biology and some implications for plasma applications to medicine and biology. J. Phys. D 2012, 45, 263001. [CrossRef]

11. Lu, X.; Naidis, G.V.; Laroussi, M.; Reuter, S.; Graves, D.B.; Ostrikov, K. Reactive Species in Non-equilibrium Atmospheric Pressure Plasma: Generation, Transport, and Biological Effects. Phys. Rep. 2016, 630, 1-84. [CrossRef]

12. Keidar, M.; Walk, R.; Shashurin, A.; Srinivasan, P.; Sandler, A.; Dasgupta, S.; Ravi, R.; Guerrero-Preston, R.; Trink, B. Cold Plasma Selectivity and the Possibility of a Paradigm Shift in Cancer Therapy. Br. J. Cancer 2011, 105, 1295. [CrossRef] [PubMed]

13. Schlegel, J.; Koritzer, J.; Boxhammer, V. Plasma in Cancer Treatment. Clin. Plasma Med. 2013, 1, 2. [CrossRef]

14. Utsumi, F.; Kjiyama, H.; Nakamura, K.; Tanaka, H.; Mizuno, M.; Ishikawa, K.; Kondo, H.; Kano, H.; Hori, M.; Kikkawa, F. Effect of Indirect Nonequilibrium Atmospheric Pressure Plasma on Anti-Proliferative Activity against Chronic Chemo-Resistant Ovarian Cancer Cells In Vitro and In Vivo. PLoS ONE 2013, 8, e81576. [CrossRef] [PubMed]

15. Laroussi, M.; Mohades, S.; Barekzi, N. Killing of Adherent and non-adherent Cancer Cells by the Plasma Pencil. Biointerphases 2015, 10, 029410. [CrossRef]

16. Laroussi, M. Effects of Low Temperature Plasmas on Proteins. IEEE Trans. Radiat. Plasma Med. Sci. 2018, 2, 229. [CrossRef]

(C) 2018 by the authors. Licensee MDPI, Basel, Switzerland. This article is an open access article distributed under the terms and conditions of the Creative Commons Attribution (CC BY) license (http://creativecommons.org/licenses/by/4.0/). 